
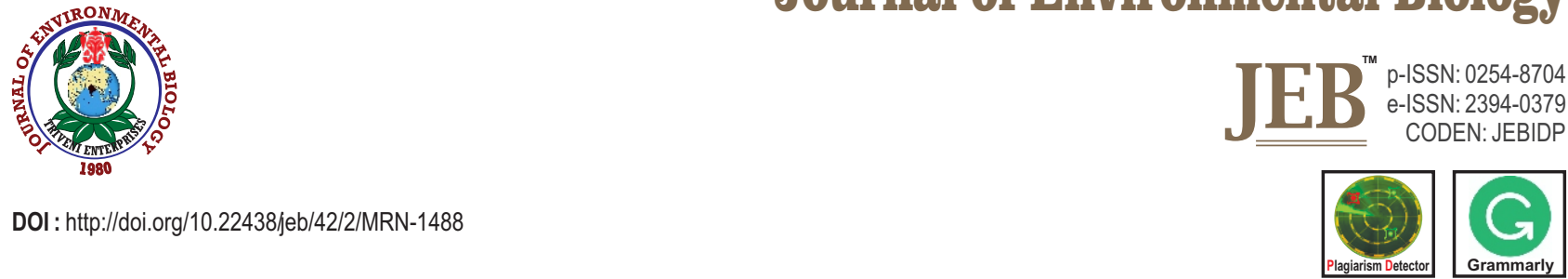

\title{
Effect of encapsulated herbicides on weed control, productivity and nutrient uptake of rice (Oryza sativa)
}

\author{
N. Bommayasamy ${ }^{1 *}$ and C.R. Chinnamuthu ${ }^{2}$ \\ ${ }^{1}$ ICAR-Central Island Agricultural Research Institute, Port Blair-744 101, India \\ ${ }^{2}$ Department of Agronomy, Tamil Nadu Agricultural University, Coimbatore-641 003, India \\ *Corresponding Author Email : samygs81@yahoo.co.in
}

\begin{abstract}
Aim: To study the effect of season-long weed management using encapsulated herbicides on weed control, productivity and nutrient uptake of rice.

Methodology: Field experiment was carried out with oxadiargyl encapsulated / loaded in zeolite, biochar, starch, water soluble polymer. It was compared with commercial formulation of oxadiargyl, butachlor, weed free check and weedy check. The experiments were laid out in randomized complete block design and replicated thrice. The physico-chemical properties of the experimental sites was sandy clay loam to clay loam in texture with $\mathrm{pH}$ ranging from 6.9 to 7.3 , low organic carbon content, low available nitrogen, medium available phosphorus and potassium.

Results: The lowest weed density and weed dry matter production of $47.3,28.0 \mathrm{~m}^{-2}$ and $96.2,32.8 \mathrm{~kg}$ ha $^{-1}$ was observed in 2016 and 2017 respectively with the application of oxadiargyl loaded with zeolite at 20 DAT. Application of butachlor at $1.25 \mathrm{~kg} \mathrm{ha}^{-1} \mathrm{fb}$ hand weeding on 40 DAT and application of oxadiargyl loaded with zeolite recorded 86.7, 76.9 and 81.3 ,
\end{abstract} 72.8 percent higher grain yield in 2016 and 2017 , respectively, as compared to weedy check. Higher N, P, K uptake was observed with application of butachlor at $1.25 \mathrm{~kg} \mathrm{ha}^{-1} \mathrm{fb}$ hand weeding on 40 DAT, which was comparable with oxadiargyl loaded with zeolite and oxadiargyl loaded with biochar during both the year.

Interpretation: It can be concluded that oxadiargyl loaded with zeolite was more efficient in controlling weeds coupled with maximum growth and productivity under the constrained situation of manual weeding.

Key words: Biochar, Encapsulation, Herbicides, Rice, Water soluble polymer, Zeolite

How to cite : Bommayasamy, N. and C.R. Chinnamuthu: Effect of encapsulated herbicides on weed control, productivity and nutrient uptake of rice (Oryza sativa). J. Environ. Biol., 42, 319-325(2021). 


\section{Introduction}

Rice (Oryza sativa) is the world's most important food crop, grown for more than 600 decades in South Asia. It is a staple food for more than 50 and 70 percent of world and Indian population, respectively. Rice is the only crop that holds key for food and nutritional security. However, rice productivity is declining day by day due to biotic stress such as weeds, pest and disease. Among these factors, weeds have been found to reduce rice productivity upto 33-45 percent in transplanted rice (Singh et al., 2007; Manhas et al., 2012; Rao and Chauhan, 2015). Manual method of weeding is an expensive, labour intensive and sometimes ineffective and inaccessible owing to frequent weed flushes during rainy season (Reddy et al., 2003). Moreover, some grassy weeds like Echinochloa colonum and E. crus-galli resembles rice plant during initial stages and therefore, escape manual removal. Hence, selection of suitable herbicides which offers effective and economical weed control right from the initial stage of crop. During last few decades, continuous use of herbicides for weed control in transplanted rice condition has not resulted in satisfactory control of sedges and broad-leaved weeds. Of late increased emphasis has also been witnessed on the use of low-dose high efficacy herbicide capable of controlling mixed flora of weeds.

The latest low dose formulations of oxadiargyl are found to be more promising for effective weed management in rice (Shekhar et al., 2009). Conventional formulations are unsafe for handling, suffer from movement of herbicide in surface run-off and leaching in soil, which is undesired in majority applications except where soil erosion results. These aforementioned problems need over application of herbicide in the case of routine formulations that may increase the latent pollution of soil and ground water. Soil applied herbicides generally disturb the natural eco-system through their effects on soil microbial and enzymatic activities, which exhibited detrimental influence on soil microflora. Most of the research works targete only critical crop weed competition. Very few study was carried out weed control throughout the crop season which has more scope to enhance rice productivity. Nano-encapsulated pesticide formulation has slow releasing mode of action with higher solubility, specificity, permeability and stability which has led to reduced, pesticide dosage with higher pesticide efficiency, enhancing productivity of crop (Bhattacharyya et al., 2016; Nuruzzaman et al., 2016, Tabana et al., 2020). Encapsulation of herbicide molecules with biodegradable polymers resulted in enhanced weed control by controlled release of herbicide.

However, encapsulated nanomaterials reduce environmental toxicity, non-target plant and over usage of herbicide (Faria et al., 2017; Kumar et al., 2017). Kumar and Chinnamuthu (2017) reported that pendimethalin encapsulated with starch releases active ingredient consistently upto 40 days under controlled environmental condition. Bommayasamy et al. (2018) reported that weeds can be effectively controlled by slow release herbicide formulations with reduced doses selectively non-toxic to crops, which remain in the soil for a long period to take care of frequently germinating weeds without leaving any residue at the end of crop season. Leaching of tebuthiuron herbicide encapsulated with calcium alginate microparticle was only to a shallow depth which resulted in minimal contamination of soil (Macedo et al., 2019; Xie et al., 2019).
Hence, development of economically viable encapsulated herbicide necessitates for slow release of their active ingredient for effective weed control. Encapsulation is an emerging technology in recent agriculture for achieving season long control, and reduces the residual effect of herbicide for succeeding season. In this background, the present study was carried out to investigate the effect of season-long weed management using encapsulated herbicides on weed control, growth, productivity and nutrient uptake of rice.

\section{Materials and Methods}

Study site: Field experiments were conducted at two locations viz., Agricultural College and Research Institute, Tamil Nadu Agricultural University, Madurai and ICAR-Central Island Agricultural Research Institute, Port Blair, Andaman and Nicobar Islands during kharif season 2016 and 2017, respectively. The soil of the experimental sites was sandy clay loam to clay loam in texture with $\mathrm{pH}$ ranging between 6.9 to $7.3,0.32$ to $0.38 \%$ organic carbon content, 246.6 to $263.4 \mathrm{~kg} \mathrm{ha}^{-1}$ of available nitrogen, 16.1 to $19.5 \mathrm{~kg} \mathrm{ha}^{-1}$ of available phosphorus and 249.0 to $284.0 \mathrm{~kg} \mathrm{ha}^{-1}$ available potassium. The experiments were laid out in randomized block design with eight treatments and replicated thrice. The treatments consist of $T_{1}$-Oxadiargyl loaded with biochar; $T_{2}$ - Oxadiargyl loaded with zeolite; $T_{3}$ - Oxadiargyl encapsulated with starch; $\mathrm{T}_{4}$-Oxadiargyl encapsulated with water soluble polymer; $\mathrm{T}_{5}$ - Oxadiargyl at $100 \mathrm{~g} \mathrm{ha}^{-1} ; \mathrm{T}_{6}$ - Butachlor at $1.25 \mathrm{~kg} \mathrm{ha}^{-1} \mathrm{fb}$ hand weeding on $40 \mathrm{DAT} ; \mathrm{T}_{7}$ - Weed free check (completely weed free by manual weeding's during 10, 25, 40, 55, 70, 85 DAT) and $\mathrm{T}_{8}$ - Weedy check. As per treatment schedule, herbicides were applied three days after transplanting.

Herbicide encapsulation/loaded procedure: Encapsulation was prepared by altering layer by layer adsorption of opposite charge polyelectrolyte onto the herbicide molecules. Prepared polyelectrolyte solution viz., Poly (allylamine hydrochloride) and Sodium poly (styrene sulfonate) weighing $20 \mathrm{mg}$ each was added to $20 \mathrm{ml}$ of $0.5 \mathrm{~N} \mathrm{NaCl}$ solution in separate beakers and dissolved it completely. Then $\mathrm{pH}$ was adjusted for the solution to $6.5-7.0$ by using $\mathrm{HCl}$ and $\mathrm{NaOH}$. Typically, $20 \mathrm{ml}$ of polyelectrolyte solution was added to $10 \mathrm{mg}$ of dry oxadiargyl and the suspension was gently stirred in magnetic stirrer for $15 \mathrm{~min}$. The suspension was then centrifuged at $1000 \mathrm{rpm}$ for $15 \mathrm{~min}$. Later the centrifuged particles were rinsed three times with $0.1 \mathrm{~N} \mathrm{NaCl}$ to remove the unbounded particles. The same procedure was repeated with oppositely charged polyelectrolyte. Alternate layer was formed using PAH and PSS. Finally, the suspension was centrifuged and allowed to dry overnight and the encapsulated particles were used for soil application. Twenty $\mathrm{mg}$ of biochar/zeolite was added to $25 \mathrm{ml}$ of $20 \mathrm{ppm}$ oxadiargyl and stirred for $15 \mathrm{~min}$ in magnetic stirrer. The suspension was then allowed to dry overnight. This enabled oxadiargyl to adsorb the biochar/zeolite. Dried herbicide loaded particles were used for application.

Experimental details and data collection: Rice variety TKM -13 was used with 130 days' duration and 30 days old seedlings were transplanted with the spacing of $20 \mathrm{~cm} \times 10 \mathrm{~cm}$ and fertilized with recommended dose of 150:50:50 kg NPK ha- ${ }^{-1}$ in the form of urea, single super phosphate and muriate of potash. Nitrogen was applied as top dressing with four equal split doses one week after 
planting, tillering, panicle initiation and flowering stage. The recommended dose of $\mathrm{P}$ and half dose of $\mathrm{K}$ were applied as basal while remaining dose of $\mathrm{K}$ was applied at panicle initiation stage. Profenophos 50 EC $1000 \mathrm{ml}^{\text {hat }}$ was applied on active tillering stage against leaf folder control as a prophylactic measure. Observation on crop growth and yield parameters were registered stage wise as per standard procedure suggested by Yoshida (1972). The weed density and dry weight were recorded at 20,60 DAT, harvest and expressed in nos. $\mathrm{m}^{-2}$ and $\mathrm{kg} \mathrm{ha}^{-1}$, respectively. Data pertaining to weeds were transformed to square root of $\sqrt{ } X+2$ and analyzed as suggested by Gomez and Gomez (2010).

\section{Results and Discussion}

In field experiment, the observed population of weeds consisted of four grasses, three sedges and six broad leaved weeds. Among the grasses, Echinochloa colonum, Leptochloa chinensis, Cynodon dactylon, Schoenoplectus juncdes, among the sedges, Cyperus rotundus, Fimbristylis miliacea, Cyperus difformis and among the broad leaved weeds Eclipta alba, Ammannia baccifera, Convolvulus arvensis, Aeschynomene indica, Bergia capensis, Sphenoclea zeylanica grew through entire crop growth period. Weed control treatments showed significant difference in weed density and weed dry matter production at 20,60 DAT and harvest. Weed free check registered significantly the least weed density and weed dry matter at all stages of crop growth. Among the weed control treatments, at 20 DAT, application of oxadiargyl loaded with zeolite recorded mean lower weed density of $37.7 \mathrm{~m}^{-2}$, which was at par with oxadiargyl loaded with biochar and oxadiargyl encapsulated with starch. These treatments recorded 40.5, 39.2 and 32.4 percent reduced weed density, respectively, as compared to application of butachlor @ $1.25 \mathrm{~kg} \mathrm{ha}^{-1} \mathrm{fb} \mathrm{HW}$ on 40 DAT. Similar finding have earlier been reported (Ahmed and Chauhan, 2015; Oliveira et al., 2015; Bommayasamy and of Chinnamuthu, 2018a) where slow release of herbicide formulations released the active ingredient continuously resulting in reduced weed density effectively. At 60 DAT, application of oxadiargyl loaded with zeolite and application of butachlor @ 1.25 $\mathrm{kg} \mathrm{ha}^{-1} \mathrm{fb} \mathrm{HW}$ on 40 DAT recorded 68.1 and 60.9 percent significantly lower weed density as compared to weedy check. It might be due to the combination of herbicide followed by hand weeding drastically reduced weed density leading to reduced built up of soil weed seed bank. Similarly, Vimalrajiv et al. (2019) reported that application of hydrogen peroxide might have reduced the germination and viability of weed seeds in turn reduced the total dry weight of weeds. Same trend was observed at harvest stage also. Weed dry matter is the most important parameter to measure the competition by weeds rather than weed number since, it precisely measures the quantity of growth related factors utilized by weeds (Bhanumurthy and Subramanian, 1989; Bommayasamy et al., 2019).

Application of oxadiargyl loaded with zeolite and oxadiargyl loaded with biochar recorded 2.16 and 1.64 times lower weed dry matter production as compared to application of butachlor @ $1.25 \mathrm{~kg} \mathrm{ha}^{-1} \mathrm{fb}$ HW on 40 DAT. Whereas at 60 DAT, the lowest weed dry matter production was observed with the application of butachlor @ $1.25 \mathrm{~kg} \mathrm{ha}^{-1} \mathrm{fb}$ HW on 40 DAT which was comparable with oxadiargyl loaded with zeolite and oxadiargyl loaded with biochar. It might be due to zeolite and biochar entrapped herbicides have increased sorption and decreased the dissipation of herbicide in soil which helps to release herbicide slowly through entire season which destroy food reserve of weed seeds and caused lesser regeneration of weeds. Similarly, Govindan and Chinnusamy (2014); Kailkhura et al. (2015); Bommayasamy and Chinnamuthu (2018b) reported that slow release of herbicide formulations reduced leaching loss of active ingredients, which affects late emerging of weeds and biomass accumulation of weeds. Microencapsulation of metazachlor with terpolymer (PLAGAPEG-PLAGA) protected degradation rate of microparticle which led to the prolong release of herbicides and reduced excess leaching into soil (Rychter et al., 2019; Lewicka et al., 2020). Throughout the crop cycle, weedy check treatment registered higher weed density and accumulated weed dry matter production. Similar trend was observed in weed dry matter production at harvest stage. Uncontrolled weeds showed reduced rice plant growth and chlorophyll content which led to poor photosynthesis capacity of crop (Hakim et al., 2015).

Weed control treatment significantly influenced the plant height, total number of tillers hill ${ }^{-1}$, dry matter production. Application of butachlor @1.25 kg ha- ${ }^{-1} \mathrm{fb}$ HW on 40 DAT recorded 15.0 and 10.7 percent higher plant height as compared to weedy check and application of oxadiargyl at $100 \mathrm{~g} \mathrm{ha}^{-1}$, respectively. Payman and Singh (2008) reported that the tallest plant height was registered in pertilachlor (@ 0.75 $\mathrm{kg} \mathrm{ha}^{-1}$ ) applied plot which was 8.18 percent higher than weedy check. The highest number of total tillers hill ${ }^{-1}$ was recorded by the weed free check which was at par with the application of butachlor @ $1.25 \mathrm{~kg} \mathrm{ha}^{-1} \mathrm{fb}$ HW on 40 DAT and oxadiargyl loaded with zeolite. This might be due to minimum competition with weeds which creates congenial environment for effective utilization of nutrients, moisture and solar radiation results in better photosynthesis and ultimately produced higher number of tillers hill ${ }^{-1}$. Chinnusamy et al. (2012) reported that herbicide application reduced weed seed germination during initial growth stage of crop which minimized nutrient depletion by weeds resulting in superior growth attributes of rice. Li et al. (2019) and Rao et al. (2020) observed that application of polyurea encapsulated oxyfluorfen showed superior crop growth than commercial products.

The least number of total tillers hill ${ }^{-1}$ was registered under weedy check. Which might be due to severe weed competition throughout the crop growth. The reduction of DMP to the tune of 39.8, 33.7 and 30.6 percent was recorded with the weedy check as compared to application of butachlor @ $1.25 \mathrm{~kg} \mathrm{ha}^{-1} \mathrm{fb} \mathrm{HW}$ on 40 DAT, oxadiargyl loaded with zeolite and oxadiargyl loaded with biochar, respectively. It might be due to the fact that minimum weed competition recorded maximum DMP, due to higher plant height, more number of tillers and leaf area index, which are the deciding parameters for dry matter production. Nano-encapsulated chemicals provide higher penetration through cuticle and slow release active ingredients resulting in effective control of weeds (Shan et al., 2012; Dhillon and Mukhopadhyay, 2015). Weed control treatments exerted significant influence in productive tillers hill ${ }^{-1}$, panicle length, panicle weight, total no of grains panicle $^{-1}$ (Table 2). Weed free check recorded higher yield attributes and yield. Among the weed control treatments, application of oxadiargyl loaded with zeolite (34.9 percent) and 
oxadiargyl loaded with biochar (31.1 percent) produced higher tillers than weedy check in 2016. Whereas, in 2017, application of butachlor at $1.25 \mathrm{~kg} \mathrm{ha}^{-1} \mathrm{fb}$ hand weeding on 40 DAT and oxadiargyl loaded with zeolite produced 31.0 and 20.8 percent more tillers, respectively, over weedy check. It might be owing to better control of weeds and dry weight which might have facilitated the crop for better uptake of essential nutrients and ultimately development of more sources to sink relationship. These results are in conformity with the findings of Parthipan et al. (2013) who reported that effective weed control creates better environment for plant growth and increases uptake of both macro and micro nutrients. Panicle length and panicle weight were significantly influenced by various weed control treatments. Application of oxadiargyl loaded with zeolite significantly increased the panicle length to 22.1 and $23.5 \mathrm{~cm}$ in 2016 and 2017, respectively, which was 4.1 and $3.7 \mathrm{~cm}$ lengthier than weedy check.

This was comparable with the application of butachlor at $1.25 \mathrm{~kg} \mathrm{ha}^{-1} \mathrm{fb}$ hand weeding on 40 DAT and application of oxadiargyl loaded with biochar. Whereas, heavier panicle was recorded in application of oxadiargyl loaded with zeolite and butachlor @ $1.25 \mathrm{~kg} \mathrm{ha}^{-1} \mathrm{fb}$ hand weeding on 40DAT which was 0.37 and $0.69 \mathrm{~g}$ higher than weedy check in 2016 and 2017 , respectively. Higher total number of grains panicle ${ }^{-1}$ of 23.1, 18.8 and 8.5, 9.5 percent were registered under application of oxadiargyl loaded with zeolite and butachlor at $1.25 \mathrm{~kg} \mathrm{ha}^{-1} \mathrm{fb}$ HW on 40 DAT in 2016 and 2017, respectively, as compared to weedy check. Encapsulated herbicide effectively controlled weed dry matter production which facilitated the crop to extract more amount of nutrient to produce higher fertile spikelet's. Similar finding was reported by Singh and Singh (2006); Maruyama et al. (2016) who suggested that encapsulation of imazapic and imazapyr herbicides using chitosan/alginate provided control release and lesser cellular damage over a period of time as compared to other formulations. Happiness et al. (2020), encapsulation of herbicides in copper polymers nanoparticle reduced negative impact on environment, non target organisms, ground water and surface water contaminations.

Weed control treatments significantly influenced grain yield during both the years (Table 3 ). Grain yield varied from 2860 to $5830 \mathrm{~kg} \mathrm{ha}^{-1}$ and 3270 to $6420 \mathrm{~kg} \mathrm{ha}^{-1}$ in 2016 and 2017 , respectively. Weed free check recorded superiorly higher grain yield as compared to all other weed control treatments. Application of butachlor @ $1.25 \mathrm{~kg} \mathrm{ha}^{-1} \mathrm{fb}$ HW on 40 DAT and oxadiargyl loaded with zeolite recorded 86.7 and 76.9 percent higher grain yield as compared to weedy check in 2016 . Whereas, in 2017, higher grain yield of 81.3, 72.8 and 67.0 percent recorded under the application of butachlor @ $1.25 \mathrm{~kg} \mathrm{ha}^{-1} \mathrm{fb} \mathrm{HW}$ on 40 DAT, oxadiargyl loaded with zeolite and oxadiargyl loaded with biochar, as compared to weedy check. These treatments were at par with one another. Due to slow release of encapsulated herbicide significantly reduced weed dry matter production which led to synthesize more food materials through effective

Table 1: Effect of encapsulated/loaded herbicide oxadiargyl on total weed density, dry weight and weed control efficiency of rice

\begin{tabular}{|c|c|c|c|c|c|c|c|c|c|c|c|c|}
\hline \multirow{3}{*}{ Treatments } & \multicolumn{6}{|c|}{ Weed density (Nos. $\mathrm{m}^{-2}$ ) } & \multicolumn{6}{|c|}{ Weed dry matter production (kg ha-1) } \\
\hline & \multicolumn{2}{|c|}{20 DAT } & \multicolumn{2}{|c|}{60 DAT } & \multicolumn{2}{|c|}{ Harvest } & \multicolumn{2}{|c|}{20 DAT } & \multicolumn{2}{|c|}{60 DAT } & \multicolumn{2}{|c|}{ Harvest } \\
\hline & 2016 & 2017 & 2016 & 2017 & 2016 & 2017 & 2016 & 2017 & 2016 & 2017 & 2016 & 2017 \\
\hline $\begin{array}{l}\mathrm{T}_{1} \text {-Oxadiargyl } \\
\text { loaded with biochar }\end{array}$ & $\begin{array}{l}7.4 \\
(53.3)\end{array}$ & $\begin{array}{l}5.9 \\
(32.3)\end{array}$ & $\begin{array}{l}10.8 \\
(115.3)\end{array}$ & $\begin{array}{l}8.9 \\
(76.3)\end{array}$ & $\begin{array}{l}12.6 \\
(157.3)\end{array}$ & $\begin{array}{l}9.9 \\
(96.3)\end{array}$ & $\begin{array}{l}10.1 \\
(99.2)\end{array}$ & $\begin{array}{l}8.3 \\
(67.2)\end{array}$ & $\begin{array}{l}21.9 \\
(479.2)\end{array}$ & $\begin{array}{l}22.2 \\
(491.4)\end{array}$ & $\begin{array}{l}27.4 \\
(749.4)\end{array}$ & $\begin{array}{l}25.2 \\
(635.3)\end{array}$ \\
\hline $\begin{array}{l}\mathrm{T}_{2} \text {-Oxadiargyl loaded } \\
\text { with zeolite }\end{array}$ & $\begin{array}{l}7.0 \\
(47.3)\end{array}$ & $\begin{array}{l}5.5 \\
(28.0)\end{array}$ & $\begin{array}{l}10.2 \\
(102.0)\end{array}$ & $\begin{array}{l}8.4 \\
(69.3)\end{array}$ & $\begin{array}{l}11.5 \\
(130.3)\end{array}$ & $\begin{array}{l}9.5 \\
(88.7)\end{array}$ & $\begin{array}{l}9.9 \\
(96.2)\end{array}$ & $\begin{array}{l}5.9 \\
(32.8)\end{array}$ & $\begin{array}{l}21.2 \\
(449.4)\end{array}$ & $\begin{array}{l}20.9 \\
(436.8)\end{array}$ & $\begin{array}{l}27.0 \\
(728.7)\end{array}$ & $\begin{array}{l}24.1 \\
(577.7)\end{array}$ \\
\hline $\begin{array}{l}\mathrm{T}_{3} \text {-Oxadiargyl } \\
\text { encapsulated } \\
\text { with starch }\end{array}$ & $\begin{array}{l}6.3 \\
(37.7)\end{array}$ & $\begin{array}{l}6.4 \\
(39.3)\end{array}$ & $\begin{array}{l}11.6 \\
(133.7)\end{array}$ & $\begin{array}{l}9.2 \\
(81.7)\end{array}$ & $\begin{array}{l}12.5 \\
(154.0)\end{array}$ & $\begin{array}{l}10.1 \\
(100.0)\end{array}$ & $\begin{array}{l}10.6 \\
(109.9)\end{array}$ & $\begin{array}{l}8.4 \\
(68.8)\end{array}$ & $\begin{array}{l}22.7 \\
(514.7)\end{array}$ & $\begin{array}{l}22.1 \\
(485.7)\end{array}$ & $\begin{array}{l}28.6 \\
(814.4)\end{array}$ & $\begin{array}{l}25.2 \\
(634.9)\end{array}$ \\
\hline $\begin{array}{l}\mathrm{T}_{4} \text {-Oxadiargyl } \\
\text { encapsulated with } \\
\text { water soluble polymer }\end{array}$ & $\begin{array}{l}8.2 \\
(65.3)\end{array}$ & $\begin{array}{l}6.2 \\
(36.3)\end{array}$ & $\begin{array}{l}11.8 \\
(138.0)\end{array}$ & $\begin{array}{l}9.5 \\
(88.3)\end{array}$ & $\begin{array}{l}13.2 \\
(173.3)\end{array}$ & $\begin{array}{l}10.5 \\
(107.7)\end{array}$ & $\begin{array}{l}11.2 \\
(123.5)\end{array}$ & $\begin{array}{l}8.1 \\
(64.1)\end{array}$ & $\begin{array}{l}23.0 \\
(526.7)\end{array}$ & $\begin{array}{l}22.6 \\
(510.5)\end{array}$ & $\begin{array}{l}29.6 \\
(872.8)\end{array}$ & $\begin{array}{l}26.3 \\
(687.4)\end{array}$ \\
\hline $\begin{array}{l}\mathrm{T}_{5} \text {-Oxadiargyl at } \\
100 \mathrm{~g} \mathrm{ha}^{-1}\end{array}$ & $\begin{array}{l}8.8 \\
(75.7)\end{array}$ & $\begin{array}{l}6.9 \\
(45.0)\end{array}$ & $\begin{array}{l}12.4 \\
(151.7)\end{array}$ & $\begin{array}{l}11.3 \\
(123.7)\end{array}$ & $\begin{array}{l}13.8 \\
(188.7)\end{array}$ & $\begin{array}{l}13.3 \\
(174.0)\end{array}$ & $\begin{array}{l}11.4 \\
(128.4)\end{array}$ & $\begin{array}{l}9.7 \\
(92.7)\end{array}$ & $\begin{array}{l}24.5 \\
(605.7)\end{array}$ & $\begin{array}{l}24.0 \\
(574.2)\end{array}$ & $\begin{array}{l}30.3 \\
(918.5)\end{array}$ & $\begin{array}{l}29.0 \\
(840.2)\end{array}$ \\
\hline $\begin{array}{l}\mathrm{T}_{6} \text {-Butachlor at } \\
1.25 \mathrm{~kg} \mathrm{ha}^{-1} \mathrm{fb} \mathrm{HW} \\
\text { on } 40 \text { DAT }\end{array}$ & $\begin{array}{l}6.4 \\
(38.7)\end{array}$ & $\begin{array}{l}9.5 \\
(88.0)\end{array}$ & $\begin{array}{l}8.0 \\
(62.3)\end{array}$ & $\begin{array}{l}8.9 \\
(77.7)\end{array}$ & $\begin{array}{l}9.0 \\
(79.7)\end{array}$ & $\begin{array}{l}9.5 \\
(87.7)\end{array}$ & $\begin{array}{l}10.8 \\
(114.0)\end{array}$ & $\begin{array}{l}12.7 \\
(158.5)\end{array}$ & $\begin{array}{l}20.2 \\
(408.3)\end{array}$ & $\begin{array}{l}20.6 \\
(424.0)\end{array}$ & $\begin{array}{l}24.4 \\
(593.0)\end{array}$ & $\begin{array}{l}23.9 \\
(569.5)\end{array}$ \\
\hline $\mathrm{T}_{7}$-Weed free check & $\begin{array}{l}1.4 \\
(0.0)\end{array}$ & $\begin{array}{l}1.4 \\
(0.0)\end{array}$ & $\begin{array}{l}1.4 \\
(0.0)\end{array}$ & $\begin{array}{l}1.4 \\
(0.0)\end{array}$ & $\begin{array}{l}1.4 \\
(0.0)\end{array}$ & $\begin{array}{l}1.4 \\
(0.0)\end{array}$ & $\begin{array}{l}1.4 \\
(0.0)\end{array}$ & $\begin{array}{l}1.4 \\
(0.0)\end{array}$ & $\begin{array}{l}1.4 \\
(0.0)\end{array}$ & $\begin{array}{l}1.4 \\
(0.0)\end{array}$ & $\begin{array}{l}1.4 \\
(0.0)\end{array}$ & $\begin{array}{l}1.4 \\
(0.0)\end{array}$ \\
\hline $\mathrm{T}_{8}$-Weedy check & $\begin{array}{l}10.0 \\
(98.7)\end{array}$ & $\begin{array}{l}11.4 \\
(128.3)\end{array}$ & $\begin{array}{l}14.6 \\
(213.3)\end{array}$ & $\begin{array}{l}15.0 \\
(225.0)\end{array}$ & $\begin{array}{l}16.8 \\
(279.7)\end{array}$ & $\begin{array}{l}16.5 \\
(270.3)\end{array}$ & $\begin{array}{l}18.1 \\
(327.9)\end{array}$ & $\begin{array}{l}21.1 \\
(441.8)\end{array}$ & $\begin{array}{l}33.2 \\
(1103.3)\end{array}$ & $\begin{array}{l}35.1 \\
(1231.8)\end{array}$ & $\begin{array}{l}39.0 \\
(1524.8)\end{array}$ & $\begin{array}{l}38.1 \\
(1457.6)\end{array}$ \\
\hline SEm \pm & 0.2 & 0.2 & 0.4 & 0.3 & 0.3 & 0.3 & 0.4 & 0.2 & 0.8 & 0.5 & 0.6 & 0.8 \\
\hline $\operatorname{LSD}(P=0.05)$ & 0.7 & 0.7 & 1.1 & 0.8 & 1.0 & 0.9 & 1.1 & 0.7 & 2.3 & 1.6 & 1.9 & 2.4 \\
\hline
\end{tabular}

Figures in parentheses are mean of original values; Data subjected to $\sqrt{ } \mathrm{x}+2$ transformation 

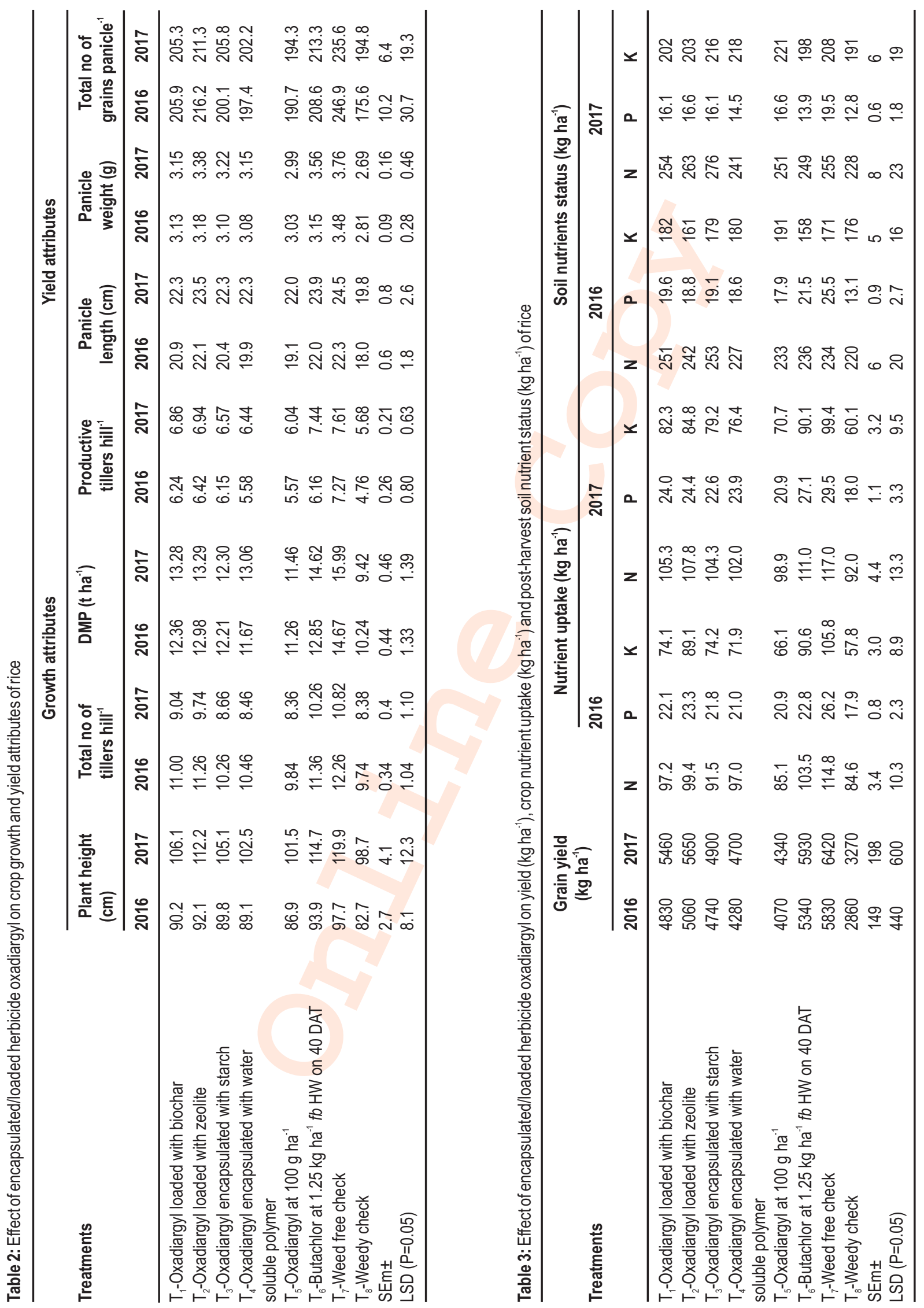
photosynthesis and deposited in plant parts resulted in enhancement of productive tillers, filled grains and higher grain yields. Application of flumioxazin plus chlorimuron followed by micro encapsulated acetochlor plus glyphosate recorded comparable yield as that of weed free treatment (Jhala et al., 2015; Pinjari et al., 2016; Tadepalli and Singh, 2017).

Crop nutrient uptake is the result of total dry matter production and plant nutrient concentration. Healthy and well developed root system extract plant nutrients with the help of roots which drives dissolution and ion exchange reactions dragging nutrients as required by plants (Yuvaraj and Subramanian, 2015). Weed free check recorded higher N, P, K uptake at all stages. Among the weed control treatments, application of butachlor @ $1.25 \mathrm{~kg} \mathrm{ha}^{-1} \mathrm{fb} \mathrm{HW}$ on 40 DAT recorded higher $\mathrm{N}, \mathrm{P}, \mathrm{K}$ uptake and it was at par with the application of oxadiargyl loaded with zeolite and oxadiargyl loaded with biochar during both the year. This might be due to application of zeolite which acted as a soil conditioner; increased fertilizer use efficiency by controlled release of nutrient in match with the requirement of plants during different physiological growth stages.

At the same time, the zeolite protects the ammonium ions from microbial conversion to nitrate ions because nitrifying bacteria are too large to fit into cage within the zeolite structure (Mackown, 1978). Evidently, the weedy check recorded the least grain yield in turn receiving the least N, P, K uptake, which might be due to maximum utilization of available resources by weeds rather than crop. Similar results reported by Puniya et al. (2007); Chakraborti et al. (2017) who demonstrated that the highest nutrient loss was observed with unweed control due to higher weed density and dry weight. Post-harvest soil available nutrient status was assessed which indicated that various weed control treatments had significant effect on available N, P, and K. Significantly lower available $\mathrm{N}$ and $\mathrm{P}$ of $220,228 \mathrm{~kg} \mathrm{ha}^{-1}$ and 13.1 , $12.8 \mathrm{~kg} \mathrm{ha}^{-1}$ was recorded in 2016 and 2017, respectively, over weedy check. This was followed by application of oxadiargyl encapsulated with water soluble polymer. The least soil available $\mathrm{K}$ of $158 \mathrm{~kg} \mathrm{ha}^{-1}$ registered with application of butachlor @ $1.25 \mathrm{~kg}$ $\mathrm{ha}^{-1} \mathrm{fb}$ hand weeding on 40 DAT which was at par with application of oxadiargyl loaded with zeolite and weed free check in 2016. Whereas, weedy check recorded the lowest soil available $\mathrm{K}$ in 2017. The least accumulation of crop biomass due to higher weed population and accumulation of more weed dry biomass cause significant depletion of soil available nutrients has also been reported by Gaurav et al. (2019). Thus from the results of the experiments, it can be concluded that oxadiargyl loaded with zeolite was more efficient in controlling weeds coupled with maximum growth and productivity under the constrained situation of manual weeding.

\section{Acknowledgments}

The authors are thankful to the Director, ICAR-Central Island Agricultural Research Institute, Port Blair and Department of Agronomy, Agricultural College and Research Institute, Tamil Nadu Agricultural University, Madurai for providing facility to carry out the research.

\section{Add-on Information}

Authors' contribution: N. Bommayasamy: Carried out the experiment and statistical analysis, prepared manuscript; C.R. Chinnamuthu: Conceived \& designed the experiment, manuscript revised and finalized.

Research content: The research content is original and has not been published elsewhere

\section{Ethical approval: NotApplicable}

Conflict of interest: The authors declare that there is no conflict of interest.

\section{Data from other sources: NotApplicable}

Consent to publish: All authors agree to publish the paper in Journal of Environmental Biology.

\section{References}

Ahmed, S. and B.S. Chauhan: Efficacy and phytotoxicity of different rates of oxadiargyl and pendimethalin in dry-seeded rice (Oryza sativa L.) in Bangladesh. Crop Prot., 72, 169-174 (2015).

Bhanumurthy, V.B. and S. Subramanian: Adoption of a new parameter, gram day competition, for weed-control study. Indian J. Agric. Sci., 59, 800-801 (1989).

Bhattacharyya, A., P. Duraisamy, M. Govindarajan, A.A. Buhroo and R. Prasad: Nanobiofungicides: Emergeing trend in insect pest control. In: Advances and Applications through Fungal Nanobiotechnology (Eds.: R. Prasad). Springer International Publishing, Cham, SL., p. 319 (2016).

Bommayasamy, N. and C.R. Chinnamuthu: Efficacy of entrapped oxadiargyl herbicide formulations on weed, growth and yield of rice in vaigai-periyar command area of Tamil Nadu. Res. J. Agric. Sci., 9, 1336-1339 (2018a).

Bommayasamy, N. and C.R. Chinnamuthu: Entrapped pre-emergence oxadiargyl on growth and yield of rice under various agro ecosystem. Indian J. Weed Sci., 50, 1-5 (2018b).

Bommayasamy, N., C.R. Chinnamuthu, N.S. Venkataraman, K. Balakrishnan and B. Gangaiah: Effect of entrapped slow release preemergence herbicide oxadiargyl with zeolite, biochar, starch and water soluble polymer formulations on weed control duration and yield of transplanted rice. Int. J. Chem. Stud., 6,1519-1523 (2018).

Bommayasamy, N., L.B. Singh, V.K. Pandey, B.K. Nanda, Harapriya Nayak and A. Kundu: Efficacy of rice cum dhaincha (Sesbania aculeata) intercropping on weed control, growth, yield and economics of rice. J. Pharmacogn. Phytochem., 8, 3257-3260 (2019).

Chakraborti, M., B. Duary and M. Datta: Effect of weed management practices on nutrient uptake by direct seeded upland rice under Tripura condition. Int. J. Curr. Microbiol. App.Sci., 6, 66-72 (2017).

Chinnusamy, C., P. Janaki, P. Muthukrishnan and S. Jeyaraman: Long term herbicidal weed management integrated with nitrogen nutrient in transplanted rice-rice cropping system of Tamil Nadu, India. Pakistan J. Weed Sci. Res., 18, 95-103 (2012).

Dhillon, N.K. and S.S. Mukhopadhyay: Nanotechnology and allelopathy: Synergism in action. J. Crop weed, 11, 187-191 (2015).

Faria, D.A., S.A. Dourada, J.P.L. Nascimento, E.S. Nunes, R.P. 
Marques, L.S. Rossina and J.A. Moreto: Development and evaluation of a controlled release system of TBH herbicide using alginate microparticles. Mater. Res., 20, 225-235 (2017).

Gaurav, S.K., R.S. Verma, R.S. Meena, A.C. Maurya and S. Kumar: Nutrients uptake and available nutrient status in soil as influenced by sowing methods and herbicides in Kharif Maize (Zea mays L.). Int. J. Agric., Environ. Biotec., 11, 17-24 (2019).

Gomez, K.A. and A.A. Gomez: Statistical procedures for agricultural research. $2^{\text {nd }}$ Edn., John Wiley \& Sons, New Yark, USA (2010).

Govindan, R. and C. Chinnusamy: Tillage, crop establishment and weed management in rice under conservation agriculture system. Indian J. Weed Sci., 46, 117-122 (2014).

Hakim, M.A., A.S.Juraimi, M.M. Hanafi, M.Y. Rafii, M.R. Ismail, S.M. Rezaul Karim and H. Kausar: Integration of herbicides with manual weeding for controlling the weeds in rice under saline environment. J. Environ. Biol., 36, 1311-1317 (2015).

Happiness, I.U., R. Wuana, N. Lami and S. Rufus: Eco-friendly 2,4-D dimethylamine herbicide delivery system using synthesized nanomatrix. Asian J. Nanosci. Mater., 3, 167-188 (2020).

Jhala, A.J., M.S. Malik and J.B. Willis: Weed control and crop tolerance of micro-encapsulated acetochlor applied sequentially in glyphosateresistant soybean. Can. J. Plant Sci., 95, 973-981 (2015).

Kailkhura, S., T. Pratap, V.P. Singh, S.K. Gaur and S.P. Singh: Herbicide combinations for control of complex weed flora in transplanted rice. Indian J. Weed Sci., 47, 414-416 (2015).

Kumar, P. and C.R. Chinnamuthu: Assembly of nanoencapsulated pendimethalin herbicide using solvent evaporation method for season long weed control under irrigated ecosystem. Int. J. Pure App. Biosci., 5, 349-357 (2017).

Kumar, S., D. Kumar and N. Dilbaghi: Preparation, characterization and bio-efficacy evaluation of controlled release carbendazim-loaded polymeric nanoparticles. Environ. Sci. Pollut. Res., 24, 926-937 (2017).

Lewicka, K., P. Dobrzynski and P. Rychter: PLAGA-PEG-PLAGA terpolymer based carriers of herbicides for potential application in environment friendly controlled released systems of agrochemicals. Materials, 13, 1-24 (2020).

Li, D., Y. Wang, J. Wang and H. Liu: Effect on the characterization of metolachlor polyurea microcapsules with urea instead of polyamines. Des. Monomers Polym., 22, 140-149 (2019).

Macedo, D.F., J.S.M. Dourado, E.S. Nunes, R.P. Marques and J.A. Moreto: Controlled release of TBH herbicide encapsulated on CaAlg microparticles: leaching and phytointoxication plants. Planta Danin., 37, 1-12 (2019).

Mackown, C.T:: Role of mineral zeolites as soil amendments. In: Natural Zeolites: Occurrence, Properties, Use (Eds.: L.B. Sand and F.A. Mumpton). Univeristy of Arizona, Tucson, AZ, p.117 (1978).

Manhas, S.S., G. Singh, D. Singh and V. Khajuria: Effect of tank-mixed herbicides on weeds and transplanted rice (Oryza sativa L.). Ann. Agric. Res., 33, 25-31 (2012).

Maruyama, C.R., M. Guilger, M. Pascoli, N. B. Jose, P.C. Abhilash, L.F. Fraceto and R. Lima: Nanoparticles based on chitosan as carriers for the combined herbicides Imazapic and Imazapyr. Sci. Rep., $\mathbf{6}$, 1-13(2016).

Nuruzzaman, M., M.M. Rahman, Y. Liu and R. Naidu: Nanoencapsulation, nano-guard for pesticides: A new window for safe application. J. Agric. Food Chem., 64, 1447-1483 (2016).

Oliveria, H.C., R. Stolf-Moreira, C.B.R. Martinez, R. Grillo, M.B. Jesus and L.F. Fraceto: Nanoencapsulation enhances the post emergence herbicidal activity of atrazine against mustard plants.
PLOS ONE, 10, 1-12(2015)

Parthipan, T., V. Ravi, E. Subramanian and T. Ramesh: Integrated weed management on growth and yield of transplanted rice and its residual effect on succeeding black gram. J. Agron., 12, 99-103 (2013).

Payman, G. and S. Singh: Effect of seed rate, spacing and herbicide use on weed management in direct seeded upland rice (Oryza sativa L.). Indian J. Weed Sci., 40, 11-15 (2008).

Pinjari, S.S., S.B. Gangawane, N.V. Mhaskar, S.A. Chavan, V.G. Chavan and D.N Jagtap: Integrated use of herbicides to enhance yield and economics of direct-seeded rice. Indian J. Weed Sci., 48, 279-283 (2016).

Puniya, R., P.C. Pandey, P.S. Bisht and D.K. Singh: Nutrient uptake by crop and weeds as influenced by Trisulfuron, Trisulfuron+ Pretilachlor and Bensulfuron-methyl in transplanted rice (Oryza sativa L.). Indian J. Weed Sci., 39, 239-240 (2007).

Rao, A.N. and B.S.Chauhan: Weeds and weed management in India a review. In: Weed Science in the Asian-Pacific Region. (Eds.: V.S Rao, N.T. Yaduraju, N.R. Chandrasena, G. Hassan and A.R. Sharma). Indian Society of Weed Science, Jabalpur, India, pp.118 (2015).

Rao, J., A.N. Chandrani, A. Powar and S. Chandra: Design and application of polyurea microcapsules containing herbicide (oxyfluorfen). Des. Monomers Polym., 23, 155-163 (2020).

Reddy, B.V., P.S. Reddy, F. Bidinger and M. Blümmel: Crop management factors influencing yield and quality of crop residues. Field Crops Res., 84, 57-77 (2003).

Rychter, P., K. Lewicka, M. Pastusiak, M. Domanski and P. Dobrzynski: PLGA-PEG terpolymers as carriers of bioactive agents, influence of PEG blocks content on degradation and release of herbicides into soil. Polym. Degrad. Stabil., 61, 95-107 (2019).

Shan, B., C. Schaaf, A. Schmidt, K. Lucia, M. Buchfelder, M. Losa and E. Arzt: Curcumin suppresess HIF-1A synthesis and VEGFA release in pituitary adenomas. J. Endocri., 214, 389-398 (2012).

Shekhar, J., B.S. Mankotia and S.P. Dev: Productivity and economics of rice (Oryza sativa) in system of rice intensification in NorthWestern Himalayas. Indian J. Agron., 54, 423-427 (2009).

Singh, P. and S.S. Singh: Effect of establishment method, fertility level and weed-management practices on aromatic rice (Oryza sativa). Indian J. Agron., 51, 288-292 (2006)

Singh, P.K., A.K. Dwivedi and Arvind: Effect of rice wheat cropping system on growth and yield attributes in eastern region of Uttar Pradesh. J. Soils Crops, 12, 125-129 (2007).

Tabana, A., M.J. Saharkhiza and M. Khorramc: Formulation and assessment of encapsulated bioherbicides based on biopolymers and essential oil. Indus. Crops Product., 149, 112348-12 (2020).

Tadepalli, S. and R. Singh: Effect of crop establishment methods and weed management practices on growth and yield of rice (Oryza sativa L.). J. Pharmacogn. Phytochem., 6, 648-652 (2017).

Vimalrajiv, B., C.R. Chinnamuthu, E. Subramanian and K. Senthil: Management of weed seed bank using nanoparticles in combination with pendimethalin and hydrogen peroxide in irrigated blackgram (Vigna mungo L.). Madras Agric. J., 106, 26-29 (2019).

Xie, Y.L., W. Jiang, F. Li, Y. Zhang, X. Liang, M. Wang and X. Zhou: Controlled release of spirotetramat using starch-chitosan-alginate encapsulation. Bull. Environ. Contam Toxicol., 104, 149-155 (2019).

Yoshida,S.:Physiological aspects of grain yield. Ann. Rev. Plant Physiol., 23, 437-464 (1972)

Yuvaraj, M. and K.S. Subramanian:Controlled-release fertilizer pf zinc encapsulated by manganese hallow core shell. Soil Sci. Plant Nutri., 61, 319-326 (2015). 